\title{
Modification of the biogeochemical cycle of silica with eutrophication*
}

\author{
Daniel J. Conley ${ }^{1}$, Claire L. Schelske ${ }^{2}$, Eugene F. Stoermer ${ }^{3}$ \\ ${ }^{1}$ Horn Point Environmental Laboratory, Center for Environmental and Estuarine Studies, University of Maryland System, \\ PO Box 775, Cambridge, Maryland 21613, USA \\ ${ }^{2}$ Department of Fisheries and Aquatic Science, University of Florida, 7922 NW 71 st Street, Gainesville, Florida 32606, USA \\ ${ }^{3}$ Center for Great Lakes and Aquatic Sciences, University of Michigan, 2200 Bonnisteel Blvd, Ann Arbor, Michigan 48109, USA
}

\begin{abstract}
Nutrient enrichment and consequent alteration of nutrient biogeochemical cycles is a serious problem in both freshwater and marine systems. The response of aquatic systems to additions of $\mathrm{N}$ and $\mathrm{P}$ is generally to increase algal biomass. The partitioning of these nutrients into different functional groups of autotrophic organisms is dependent upon both intrinsic and extrinsic factors. A common response to nutrient loading in northern temperate aquatic ecosystems is an increase in diatom biomass. Because nutrient enrichment generally leads to increases in water column concentrations of total $\mathrm{N}$ and total $\mathrm{P}$ (and not Si) such nutrient loading can lead to transient nutrient limitation of diatom biomass due to lack of dissolved silicate (DSi). Increased production of diatom biomass can lead to an increased accumulation of biogenic silica in sediments, ultimately resulting in a decline in the water column reservoir of DSi. Such biogeochemical changes in the silica cycle induced by eutrophication were first reported for the North American Laurentian Great Lakes. However, these changes are not a regional problem confined to the Great Lakes, but occur in many freshwater and marine systems throughout the world. Here we summarize the effects of anthropogenic modification of silica biogeochemical cycles for the North American Laurentian Great Lakes, describe some of the biogeochemical changes occurring in other systems, and discuss some of the ecological implications of a reduction in water column DSi concentrations, including changes in species composition, as DSi concentrations become limiting to diatom growth and biomass, changes in food web dynamics, and altered nutrient-recycling processes.
\end{abstract}

\section{INTRODUCTION}

Human activities have increased the input of both nitrogen and phosphorus to aquatic ecosystems. These nutrients enter surface waters as agricultural runoff, from septage and sewerage discharges, from groundwater inputs, and from the atmosphere, and may stimulate the growth of phytoplankton. This cultural eutrophication of natural waters has been associated with low dissolved oxygen concentrations, declining

\footnotetext{
- Contribution no. 2461 of UMCEES and contribution no. 560 of the Center for Great Lakes and Aquatic Sciences, University of Michigan
}

fish and shellfish stocks, increased frequency of novel and toxic algal blooms and other ecosystem level alterations.

While nitrogen and phosphorus are the 2 most important nutrients governing overall algal growth (Ryther \& Dunstan 1971, Schindler 1977, Hecky \& Kilham 1988), the ratios of nutrients present (Tilman et al. 1982) and availability of dissolved silicate (Kilham 1971, Egge \& Aksnes 1992) can regulate the species composition of phytoplankton assemblages (Fig. 1). Growth of diatoms depends on the presence of dissolved silicate (DSi), whereas growth of non-diatom phytoplankton does not. When concentrations of DSi become low, other types of algae that do not require 


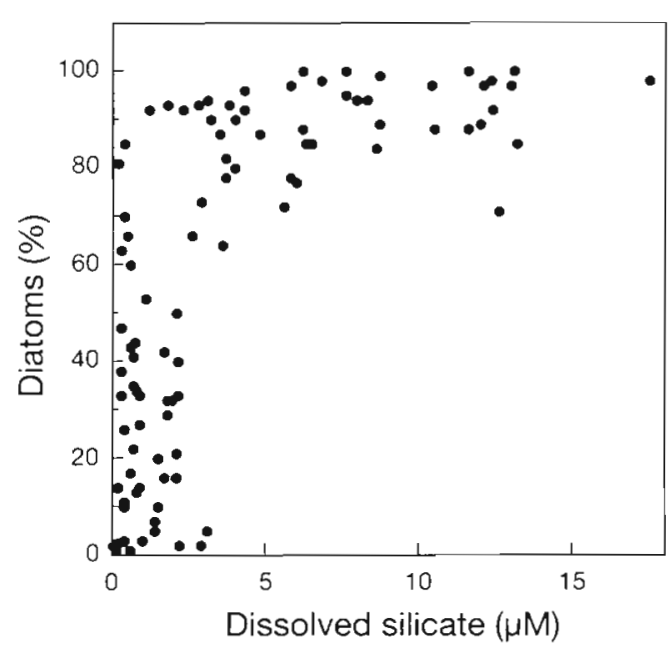

Fig. 1. Percentage of total cell counts that were diatoms in the phytoplankton community from experimental mesocosms as a function of DSi concentration (redrawn from Egge \& Aksnes 1992). Data were collected throughout the time course of the experiment from 14 separate diverse enclosure experiments, with a variety of aims, carried out in different seasons and with different nutrient inputs

DSi can dominate algal community composition and decrease the relative importance of diatoms in phytoplankton communities.

Schelske \& Stoermer $(1971,1972)$ advanced the hypothesis that anthropogenic inputs of phosphorus to Lake Michigan, USA, increased diatom production, ultimately depleting the reservoir of DSi in the lake. It was subsequently shown (Schelske et al. 1983) that, in the lower North American Great Lakes (Lake Ontario and Lake Erie), biogeochemical depletion of DSi first occurred following European settlement of the region (1840 to 1860 ), due to increased inputs of phosphorus from human activities in the watershed such as forest clearance and agriculture. In Lake Michigan, DSi depletion occurred later (1950 to 1970), and was associated with increases in phosphorus loading from phosphatebased detergents, human wastes, and fertilizer use in the watershed.

Schelske \& Stoermer $(1971,1972)$ also hypothesized that the limitation of diatom flora by reduced DSi supplies would lead to drastic and undesirable changes in the ecosystem where the phytoplankton community was dominated by green and blue-green algae during summer when DSi was limiting for diatoms. The hypothesis that modification of the phytoplankton flora would occur with eutrophication was formalized and its implications were discussed for the coastal ocean and marine systems by Officer \& Ryther (1980) and Ryther \& Officer (1981). These 2 studies identified essentially 2 distinctly different phytoplankton-based ecosystems; one dominated by diatoms and the other a non-diatom ecosystem usually dominated by flagellates, including dinoflagellates, chrysophytes, chlorophytes and coccolithophores, which may also contain large proportions of non-motile green and blue-green algae. They suggested that the diatom food web contributed directly to large fishable populations, that other algal-based food webs were undesirable either because species remain ungrazed or fuelled food webs that are economically undesirable, and that changes in species composition would lead to oxygen depletion in bottom waters. Several more recent studies have examined the role of DSi in regulating phytoplankton composition and its impacts on diatoms in food web dynamics (Doering et al. 1989, Dortch et al. 1992, Egge \& Aksnes 1992).

We want to differentiate clearly between 2 types of modification of the silica biogeochemical cycle that occur with eutrophication. The first occurs as $\mathrm{N}$ and $\mathrm{P}$ are added to aquatic systems through anthropogenic activities. Because DSi is not added to any significant extent with nutrient enrichment (Officer \& Ryther 1980 ) additions of $\mathrm{N}$ and $\mathrm{P}$ will change the $\mathrm{Si}: \mathrm{N}$ and $\mathrm{Si}$ : $\mathrm{P}$ ratios of receiving waters. These changes alone can have a substantial impact on ecosystem dynamics. However, the effects we review here are of a second type: a reduction in the water column silica reservoir through a modification of the biogeochemical cycling of silica. Increased diatom production results in increased deposition and preservation of diatom silica in sediments, which in turn leads to reductions in water column DSi concentrations.

The purpose of this review is to demonstrate how phytoplankton communities in many freshwater and coastal marine systems have been modified by eutrophication. We will demonstrate that system level changes in the biogeochemical cycling of silica reported for the North American Laurentian Great Lakes are not a strictly regional phenomenon, but a general trend in aquatic systems that occurs with eutrophication. Serious ecosystem changes that may occur with changes in the biogeochemical cycling of silica with eutrophication will be discussed, including changes in species composition and food web dynamics, role of increased frequency of toxic and novel algal blooms, and altered nutrient cycling processes.

\section{GREAT LAKES}

The silica depletion hypothesis formulated by Schelske \& Stoermer $(1971,1972)$ rests on 2 major assumptions: (1) that increased nutrient loading causes an increase in phytoplankton production, especially diatoms, and (2) that some fraction of the diatoms produced are permanently lost from the water column and sequestered in the sediments. The ultimate effect is a 
depletion of water column DSi concentrations. There are numerous lines of evidence supporting the hypothesis that the biogeochemical cycle of silica has been modified in the North American Laurentian Great Lakes. These include long-term increases in nutrient loading, changes in algal community composition, declines in water column DSi concentrations, experiments on the effect of phosphorus enrichment on natural phytoplankton assemblages, and paleolimnological evidence of increased accumulation of biogenic silica and historical changes in diatom species composition. Some or all of these lines of evidence have been reported from other aquatic environments.

\section{Long-term increases in nutrient loading}

That increases in nutrient loading have occurred in many aquatic systems due to anthropogenic activities is undisputed, however, the magnitude and timing of increases in nutrient loading are generally unknown. At best, long-term monitoring programs to measure nutrient concentrations have been established within the last 50 yr. To overcome this, Chapra (1977) constructed a historical loading model to simulate total $\mathrm{P}$ budgets for the Great Lakes as a tool to estimate the long-term effect of human activities on the water quality of the Lakes. Chapra (1977) generated P loadings from variables indicative of human development in the basin, such as population increases, changes in land use patterns, and development of sewerage systems. Historical reconstruction of total P concentrations in the Great Lakes (Fig. 2) responds to 2 major

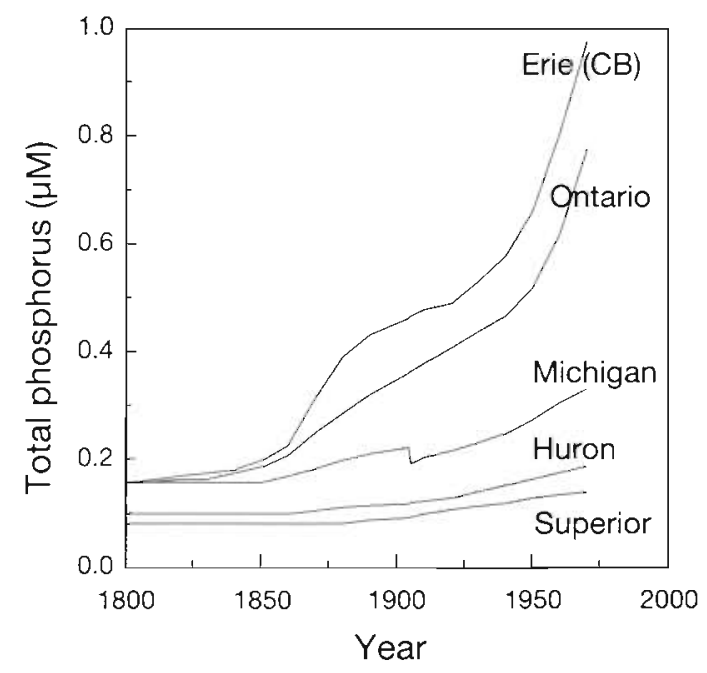

Fig. 2. Historical reconstruction of annual mean water column total phosphorus concentrations for the North American Great Lakes simulated by a loading model (redrawn from Chapra 1977) periods of increased P loading (Chapra 1977). Initial increases in water-column total $P$ concentration resulted from a change from forested to agricultural land use. A second more dramatic increase since 1945 resulted from increased sewering, population growth, and the introduction of phosphorus-based detergents. The effects are smaller for Lake Huron and Lake Superior due to lower population densities in their watersheds. In addition, larger increases in total $\mathrm{P}$ in Lake Erie and Lake Ontario as compared to the upper Great Lakes following forest clearance result partly from differences in soil composition and the ratio of drainage basin size to lake surface area. These increases in $\mathrm{P}$ loading had substantial impacts upon water quality and on phytoplankton assemblages in the Great Lakes.

\section{Long-term changes in algal community composition}

Long-term changes in phytoplankton community composition and more specifically long-term changes in diatom species composition and biomass for the North American Great Lakes are difficult to assess because of infrequency of data collection and varied quality of taxonomic identification. The most complete sets of samples are those taken from intakes of water treatment plants. However, these records of long-term phytoplankton data represent only coastal-zone populations; previous research has shown that inshore phytoplankton populations differ markedly from offshore populations and water intake data, therefore, are not representative of the lake as a whole. More complete records of changes in diatom species composition are discussed below from paleolimnological studies.

\section{Long-term records of changes in DSi concentrations}

Powers \& Ayers (1967) first reported that DSi concentrations in Lake Michigan decreased approximately $66 \mu \mathrm{M}$ from 1926 to 1964 , based on data from water samples collected at water filtration plants for the city of Chicago. Although a further evaluation of this data set is partly complicated by changes in methodology (Shapiro \& Swain 1983), the more recent records since the early 1950s using modern methodology (Fig. 3) do show consistent and statistically significant declines in open-water DSi concentrations (Schelske 1988). In addition, an independent set of data calibrated with the relatively invariant DSi concentration in Lake Superior showed that summer epilimnetic DSi in Lake Michigan decreased at least $33 \mathrm{mM}$ from 1954 to 1971 (Schelske 1985b). 


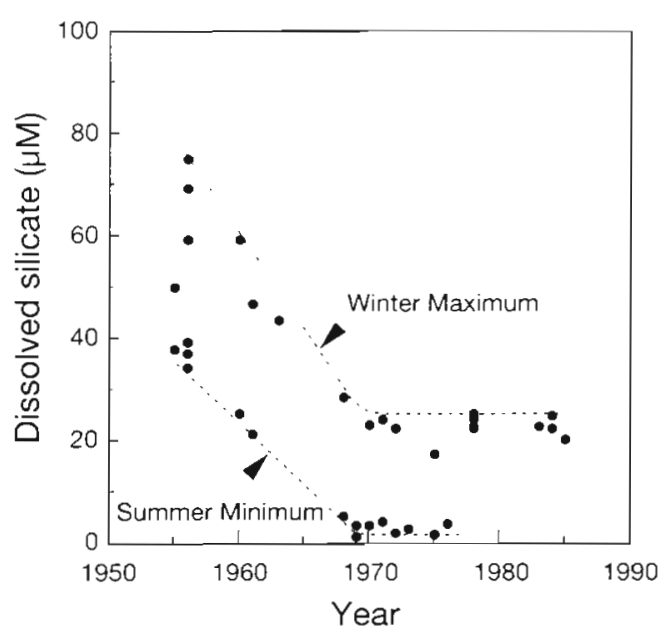

Fig. 3. Historical changes in DSi concentrations in Lake Michigan (redrawn from Schelske 1988)

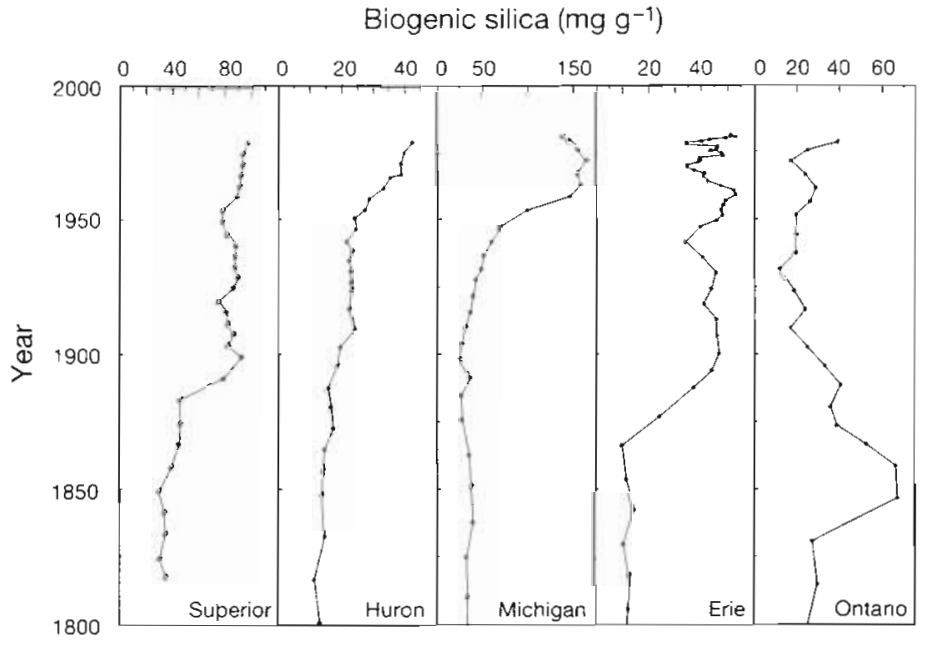

Fig. 4. Historical changes in biogenic silica accumulation in the North American Great Lakes (redrawn from Schelske et al. 1983, 1986a)

\section{Nutrient enrichment experiments}

Nutrient enrichment experiments with natural phytoplankton assemblages demonstrated the sensitivity of Great Lakes phytoplankton to small increases in P loading. In these phosphorus-limited systems small additions of dissolved phosphate increased the production of diatoms depleting DSi supplies to levels limiting for diatom growth (Schelske \& Stoermer 1972). Without phosphorus additions, diatom growth and production were reduced and no significant depletion of DSi occurred. These experiments confirmed one of the tenets of the silica depletion hypothesis: that phosphorus enrichment increases diatom production, depleting the reservoir of DSi in the water and leading to DSi-limited diatom growth (see Schelske et al. 1986b).

\section{Paleolimnological studies of biogenic silica accumulation in sediments}

Paleolimnological evidence based on accumulation of biogenic silica in sediments has been used to study the time course of depletion of DSi in the water column (Schelske et al. 1983, 1986a). Because historical data on water chemistry are limited, paleolimnological studies are the best means available to assess the historical impact of phosphorus enrichment on lake productivity (Schelske 1991, Schelske \& Hodell 1991). An initial increase in accumulation of biogenic silica in the mid- to late 1800s in the sediments of Lake Ontario and Lake Erie (Fig. 4; Schelske et al. 1983, 1988) occurred in response to increased loading of phosphorus resulting from land clearing and early settlement by Europeans (Chapra 1977). A peak in biogenic sílica accumulation occurs from a stimulation of phosphoruslimited diatom production for 1 or 2 decades until epilimnetic diatom production becomes limited by DSi supplies. Accumulation of biogenic silica in sediments depletes the water column reservoir of DSi, ultimately leading to a decline of biogenic silica accumulation in sediments. In Lake Michigan, the analogous peak associated with epilimnetic DSi depletion occurred much later, in the 1950s and 1960s (Stoermer et al 1990a). Secondary peaks in biogenic silica accumulation in Lake Erie and Lake Ontario sediments also occurred in the 1950s and 1960s due to development of severe DSi depletion throughout the year (Stoermer et al. 1985b, 1987. Schelske et al. 1986a, Schelske 1991) following exponential increases in phosphorus loading beginning in the 1940s (Chapra 1977). Accumulation of biogenic silica in Lake Superior and Lake Huron has increased, however, decreases in biogenic silica accumulation have not been observed because diatom production in the water column is not yet DSi limited (Stoermer et al. 1985a, Wolin et al. 1988).

Analyses of both biogenic silica accumulation and siliceous microfossil abundance in sediments demonstrate that 2 stages of DSi depletion can occur with eutrophication in large, deep lakes such as the Great Lakes. The first stage, epilimnetic DSi depletion, occurs from utilization of the DSi reservoir in surface waters during summer stratification (Schelske et al. 1983). The second stage, severe DSi depletion, occurs when DSi reserves in the entire water column are depleted to levels limiting for diatom production throughout the year (Stoermer et al. 1985b, Schelske et al. 1986a, Schelske 1991). Historical patterns of biogenic silica accumulation in the sediments can therefore be used to infer changes in DSi concentrations in the water column. 


\section{Paleolimnological studies of diatom accumulation in sediments}

Paleolimnological studies of diatom species composition from sediments in the Great Lakes demonstrate that significant changes have occurred with eutrophication (Frederick 1981, Harris \& Vollenweider 1982 Stoermer et al. 1985a, b, d, 1987, 1990b, Wolin et al. 1988). Algal community composition changes can occur at 2 levels. First, initial reductions in DSi concentration confer competitive advantage on diatom populations which are physiologically adapted to relatively low DSi concentrations or which are adapted to seasons (e.g. vernal circulation) or situations (e.g. upwellings) where DSi concentrations are maximal. Prolonged and severe depletion eventually results in communities dominated by taxa from divisions which do not require DSi for growth. A generalizable sequence in diatom assemblage composition associated with eutrophication and consequent depletion of DSi in the Laurentian Great Lakes is briefly described below; more detail can be found in Stoermer (1993).

Prior to European settlement, low and constant rates of diatom accumulation composed of species from a wide variety of habitats and seasons can be observed in sediment cores. We assume this represents a quasiequilibrium state of the system in which diatom community composition was determined mostly by interspecific competition of species relatively successful in sequestering very low but relatively constant phosphorus supplies. Compositional changes in diatoms correspond with deforestation, particularly increased abundance of species which inhabit the summer epilimnion and deep chlorophyll maximum. This summer association has classically been considered an indicator of oligotrophy [the oligotrophic Cyclotella association of Hutchinson (1967)]. We assume these changes in species composition signal initial increases in phosphorus loading which allow summer-blooming populations to utilize more of the epilimnetic DSi reservoir

Further increases in nutrient loading enormously increase diatom accumulation rates with a marked increase in dominance of winter-blooming species. In the Laurentian Great Lakes these are mainly species such as Aulacoseira islandica and $A$. italica, which are considered indicators of oligotrophic to mesotrophic conditions in the classical literature. Other trends include disappearance of some native benthic diatom populations, and decrease in abundance of summerblooming Cyclotella species. We assume this signals further increases in phosphorus loading, resulting in transient DSi limitation in the summer epilimnion and 'shading out' of some previously available benthic habitats by increased planktonic biomass (Brush \& Davis 1984, Stoermer et al. 1985d). Summer DSi limitation leads to a reduction in diatom accumulation, a strong shift to diatom species with apparent abundance maxima at very low temperatures, disappearance of summer-blooming Cyclotella populations, and probably a resultant shift from diatoms to phytoplankton which do not require DSi for growth.

In the final stage of depletion under very high phosphorus loading, DSi concentrations are maintained at low levels year round, and diatom accumulation is primarily composed of winter-blooming species (particularly small species of Stephanodiscus) and exotic populations particularly adapted to thermal bar conditions such as S. binderanus (Stoermer 1978). Low concentrations of DSi throughout the year convey a competitive advantage on diatom species which compete best for DSi (small Stephanodiscus spp.), or are best situated to sequester new DSi supplies delivered by streams (S. binderanus) or supplies recycled from sediment (Actinocyclus).

Coincident with changes in species composition with eutrophication are reductions in silicification of some diatoms found in Great Lakes sediments. The degree of diatom silicification, in general, reflects available DSi supplies, such that variations in valve morphology of Aulacoseira islandica and Stephanodiscus niagarae found in sediments of Lake Ontario correlate to increased phosphorus loading and consequent DSi depletion (Theriot \& Stoermer 1984, Stoermer et al. 1985c, 1989). More heavily silicified frustules are observed in sediments deposited prior to settlement of the Lake Ontario basin, with lightly silicified forms more abundant upcore as the reservoir of DSi declined in the lake.

\section{Criticism of the silica depletion hypothesis}

The silica depletion hypothesis advanced by Schelske \& Stoermer $(1971,1972)$ has been criticized on several grounds. Firstly, only a small fraction of the diatoms produced in the water column were preserved in the sediments. Conway et al. (1977) described the seasonal DSi depletion in Lake Michigan and calculated that $95 \%$ of diatom silica produced during an annual cycle must be regenerated in order to support the next spring diatom bloom. However, the annual cycle of DSi, a normal sequence of events in many lakes and marine systems, should not be confused with long-term historical depletion of the water column DSi reservoir. Schelske (1985a) demonstrated that, even though most of diatom production is recycled on an annual basis, only a small percentage of diatom production need be lost in long-residence-time systems 
in order to effect a major biogeochemical change in the water column.

Questions were also raised as to whether the sediments can be a permanent sink for biogenic silica Parker \& Edgington (1976) found that the concentration of diatom frustules decreased by 2 orders of magnitude downcore in sediments from Lake Michigan. They attributed changes in abundance only to dissolution of diatom frustules and concluded 'that sediments do not appear to be an important sink of silica in the lake'. However, Stoermer et al. (1990b) demonstrated that the abundance of diatoms in Lake Michigan sediments does not show a continual logarithmic decrease and that concomitant changes in diatom species composition were more likely due to eutrophication effects and not simply a preservation artefact.

More recently, Edgington (1984) argued that historic changes in phytoplankton community structure in Lake Michigan were not a eutrophication effect from phosphate enrichment, but rather due to effects caused by top-down control of phytoplankton communities by higher trophic levels. However, it has been clearly demonstrated that the spring bloom in Lake Michigan is terminated by the depletion of DSi and the subsequent sinking of intact diatoms, not by grazing from higher trophic levels (Scavia \& Fahnenstiel 1987).

\section{Depletion mechanism}

Changes in accumulation of biogenic silica in sediments have long been used by geologists as a proxy for water column productivity. Although the relationship between diatom production in the water column and preservation of diatoms in sediments is not necessarily linear, preservation depends upon a variety of factors including $\mathrm{pH}$, salinity, temperature, sediment type, and bulk sedimentation rate (Hurd 1983, Pokras 1986. Conley \& Schelske 1989); in general, accumulation of biogenic silica in sediments mimics overlying water column productivity. The more diatoms that are produced by nutrient-enhanced growth, the more biogenic silica will be deposited in sediments, which can eventually deplete the water column reservoir of DSi.

It has been noted that there are striking differences in the biogeochemical controls of recycling rates of $N$ and $P$ versus Si (summarized by Officer \& Ryther 1980); the regeneration of $\mathrm{Si}$ is slow relative to both $\mathrm{N}$ and $\mathrm{P}$. Regeneration of biogenic silica is primarily a chemical phenomenon whereas the regeneration of $\mathrm{N}$ and $\mathrm{P}$ are biologically mediated by grazers and bacteria. In addition, $P$ may be remineralized autolytically, whereas $N$ is strictly biologically mediated (Garber 1984). Therefore, both $N$ and $P$ will be recycled faster and reused on shorter time scales than Si.
In systems with long hydrodynamic residence times, e.g. the North American Laurentian Great Lakes, the effect of anthropogenic nutrient inputs is more pronounced. In Lake Michigan, annual Si inputs equal only $5 \%$ of the total mass resident in the water, so that small changes in recycling rates can, in a few years, have a major impact on the overall mass balance (Schelske 1985a). In aquatic systems with short residence times, DSi supplies are generally replenished annually with water renewal; the dominant input of DSi to most aquatic systems occurs with riverine inputs as a consequence of weathering reactions in the watershed. Aquatic systems with long residence times have a greater potential for reductions in the reservoir of DSi with increases in nutrient loading. In addition, in many coastal marine systems (e.g. Chesapeake Bay, USA), where nutrient supplies are generally renewed every 3 to $6 \mathrm{mo}$, one should also not expect to see long-term depletion of DSi with eutrophication, although seasonal depletion of DSi is observed with the spring diatom bloom (Conley \& Malone 1992).

\section{OTHER LAKES}

Reports of anthropogenic modification of algal communities with nutrient enrichment in lakes are numerous and there are some well-known examples of how the establishment of nutrient controls can have a substantial impact on the ecosystem (e.g. Lake Washington; Edmondson 1991). However, there are few long-term data sets available which document changes in the biogeochemical cycle of silica with eutrophication, partly because DSi is not measured routinely along with other nutrient elements in many monitoring programs, such as Lake Washington. We do know that increases in sediment accumulation of biogenic silica have occurred with eutrophication in many lakes (Schelske et al. 1983, 1986a, 1987, Engstrom et al. 1985, Schelske 1991). In fact many eutrophication changes can be very subtle; for example Stoermer et al. (1990a) reported small increases in the rate of biogenic silica accumulation and attributed concurrent changes in diatom species composition in ultraoligotrophic McLeod Bay of Great Slave Lake, Canada, to atmospheric loading of nutrients.

Few reports of DSi concentrations exist for lakes that have been artificially fertilized to study the effects of eutrophication. In an experimental fertilization of Arctic lakes, welch et al. (1989) did measure DSi and reported decreases in water column DSi concentrations in P \& N Lake and possibly Jade Lake (N.W.T., Canada) with phosphorus enrichment, including subsequent increases in water column chlorophyll concentrations. It should be noted, however, that not all lakes 
they fertilized responded with a change in DSi concentration. In some lakes (e.g. Far Lake), Welch et al. (1989) did not observe increases in water column chlorophyll or changes in DSi, but did observe increases in benthic diatom production. Not all systems that are enriched with nutrients should be expected to modify their biogeochemical silica cycle as there are many intrinsic and extrinsic factors affecting nutrient recycling processes in aquatic systems.

Analysis of long-term data on nutrient concentrations in Lake Windermere, UK, by Talling \& Heaney (1988) showed that increased P loading led to higher dissolved phosphate concentrations in winter, which in turn led to a more rapid seasonal depletion of DSi during the spring diatom bloom (Fig. 5). Although DSi concentrations do not show any significant long-term change, seasonal changes in utilization have occurred. Winter DSi concentrations in the shallow productive basin of Esthwaite Water, UK, are also occasionally reduced by exceptional diatoms blooms (Talling \& Heaney 1988). Bukaveckas \& Likens (1992) noted a significant long-term decline in outlet DSi concentrations, increases in outlet phosphorus concentrations, and declines in lake-wide Si:P ratios in Mirror Lake, USA. Because inlet concentrations to Mirror Lake have not decreased, these results suggest that in-lake retention of DSi has increased in response to greater phosphorus loadings. Increased utilization of DSi by diatoms with phosphorus enrichment in Lake Windermere or Mirror Lake will probably not lead to longterm biogeochemical declines in DSi concentrations because of the short residence times and rapid renewal of DSi supplies in these systems.

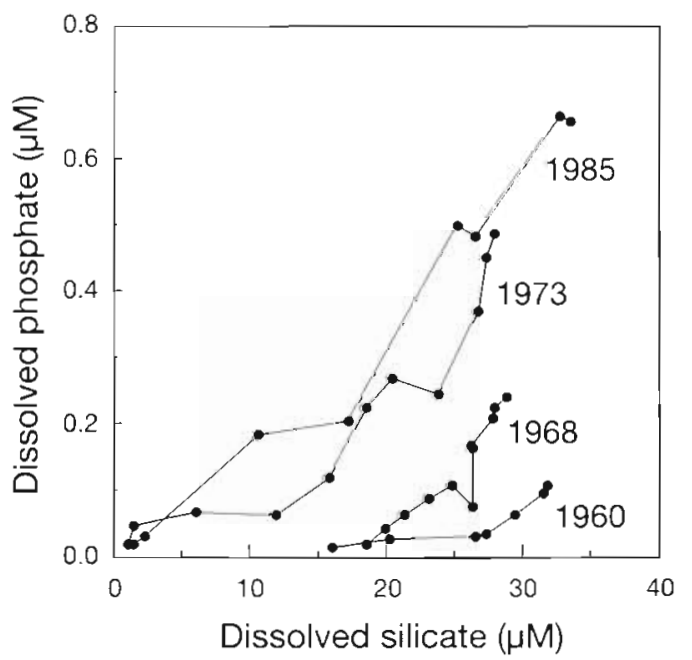

Fig. 5. Increases in vernal depletion of DSi during the spring diatom bloom with increased concentrations of dissolved phosphate in Lake Windermere (redrawn from Talling \& Heaney 1988)

\section{RIVERS}

It is well known that lakes retain some proportion of the diatoms produced in the water column in their sediments. Creation of artificial lakes (reservoirs) in riverine systems has allowed deposition and preservation of diatom silica in sediments deposited behind dams, whereas otherwise increased production did not result in biogeochemical losses from the system, because diatoms were recycled and not buried. This loss of Si has resulted in declines of DSi in river waters in many areas of the world and has been termed the 'artificial-lake effect' (van Bennekom \& Salomons 1981). Decreases in riverine DSi concentrations, therefore, may lead to a decline in transport of DSi to the oceans from the world's rivers and will probably continue to decrease with increased eutrophication.

A spectacular example of DSi loss due to this artificiallake effect has been reported in the River Nile, Egypt, where a $200 \mu \mathrm{M}$ drop in DSi concentrations was observed after completion of the Aswan High Dam (Wahby \& Bishara 1980). Mayer \& Gloss (1980) reported a $120 \mu \mathrm{M}$ decline in DSi concentrations in the $12 \mathrm{yr}$ following completion of the Glen Canyon Dam on the Colorado River, USA. Turner \& Rabalais (1991) documented a $50 \%$ decline in DSi from the 1950 s to the 1980 s concomitant with a doubling of nitrate concentrations in the Mississippi River, USA. Declines in DSi concentration in the Mississippi River were significantly correlated $\left(r^{2}=0.79\right)$ with the use of phosphorus fertilizer (Fig. 6). Admiraal et al. (1990) observed loss of DSi from the sedimentation of biogenic silica (diatom silica) in man-made sedimentation areas in the Rhine River delta, The Netherlands. Observations suggest that reductions in DSi in the Rhine River may have contributed to the incidence of non-diatom phytoplankton blooms in Dutch coastal waters (Admiraal et al. 1990).

\section{COASTAL ENVIRONMENTS}

\section{Adriatic Sea}

The Adriatic Sea is an extremely productive system that has experienced problems with cultural eutrophication from an ever-increasing load of nutrient inputs (Degobbis 1989). Riverine inputs of $N$ and $P$ have increased substantially over several decades as a consequence of increasing use of fertilizer and detergents (D. Justić, N. N. Rabalais, R. E. Turner \& Q. Dortch unpubl.). Trends of dissolved oxygen content of the northern Adriatic Sea have demonstrated that productivity is increasing and the frequency of reduced oxygen concentrations in bottom waters is increasing (Justić et al. 1987). An extensive analysis of long-term trends in nutrient ratios in the northern Adriatic Sea has shown that where once DSi was in excess relative to $N$ 

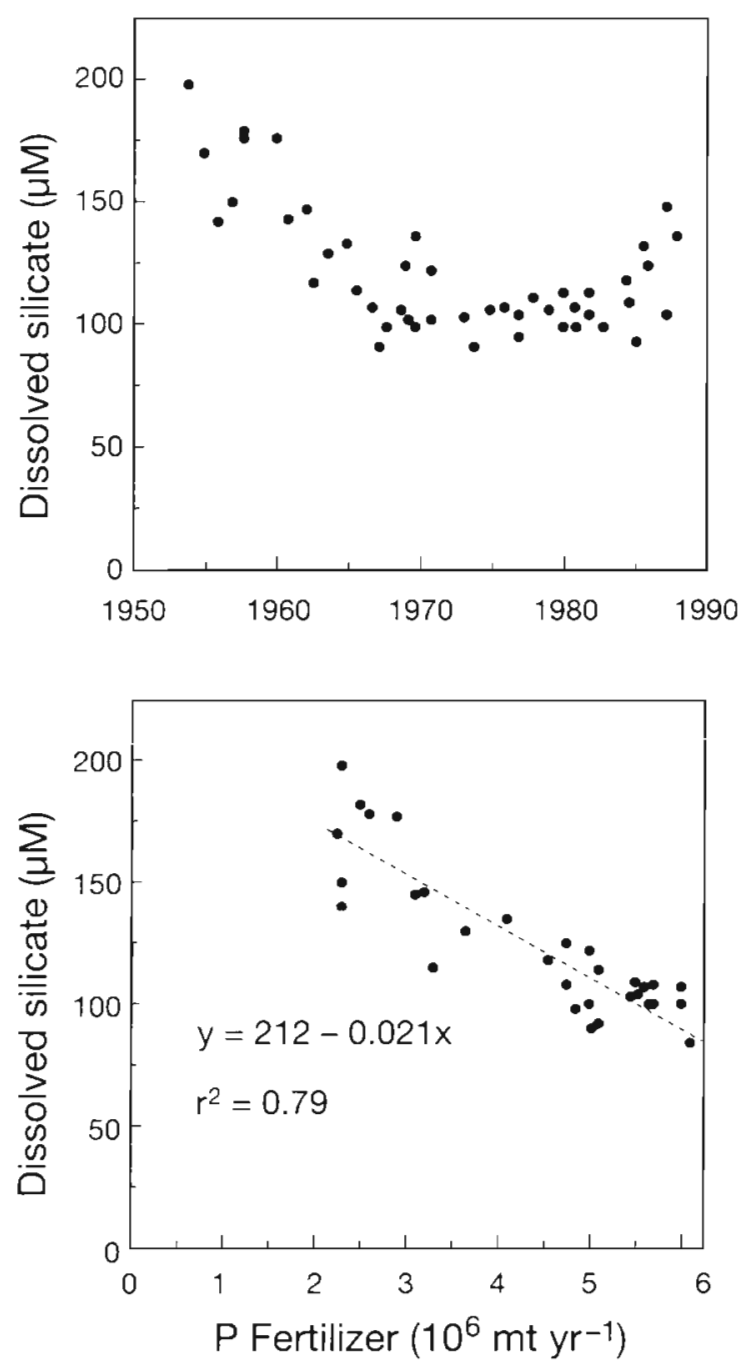

Fig. 6. Historical changes in annual average DSi concentrations in the Mississippi River at New Orleans and St. Francisville (top), and the relationship between annual average fertilizer use in the U.S. and annual average DSi concentrations in the Mississippi River at St. Francisville (redrawn from Turner \& Rabalais 1991)

and $\mathrm{P}$, the frequency of potential nutrient limitation by DSi has increased substantially over the last 15 to $30 \mathrm{yr}$ (Justić et al. unpubl.). In addition, a dramatic increase in accumulation of siliceous microfossils in sediments deposited during the last $40 \mathrm{yr}$ from the northern Adriatic has been reported (Puškarić et al. 1990).

\section{Black Sea}

Smayda (1990) reported long-term increases in dissolved phosphate concentrations, decreases in DSi concentrations, and coincident increases in the abundance of the red-tide dinoflagellate Exuviaella cordata along the Romanian coast of the Black Sea.

\section{Baltic Sea}

Wulff \& Rahm (1988) noted that the total mass of DSi in the water column has decreased throughout the entire Baltic Sea and that these changes were most pronounced during the spring diatom bloom. They calculated corresponding increases in inorganic and total $\mathrm{N}$ concentration during the same period, whereas total $\mathrm{P}$ had not changed significantly. A more detailed analysis by Sandén et al. (1991) using nonparametric trend analysis showed significant trends of decreasing DSi concentrations for the time series 1968 to 1986 (Fig. 7). Although increases in DSi concentration have occurred at Station BY15 in the bottom waters of the Gotland Deep with stagnation, the amount of increase cannot nearly account for DSi declines observed throughout the entire Baltic Sea. Depletion of DSi has

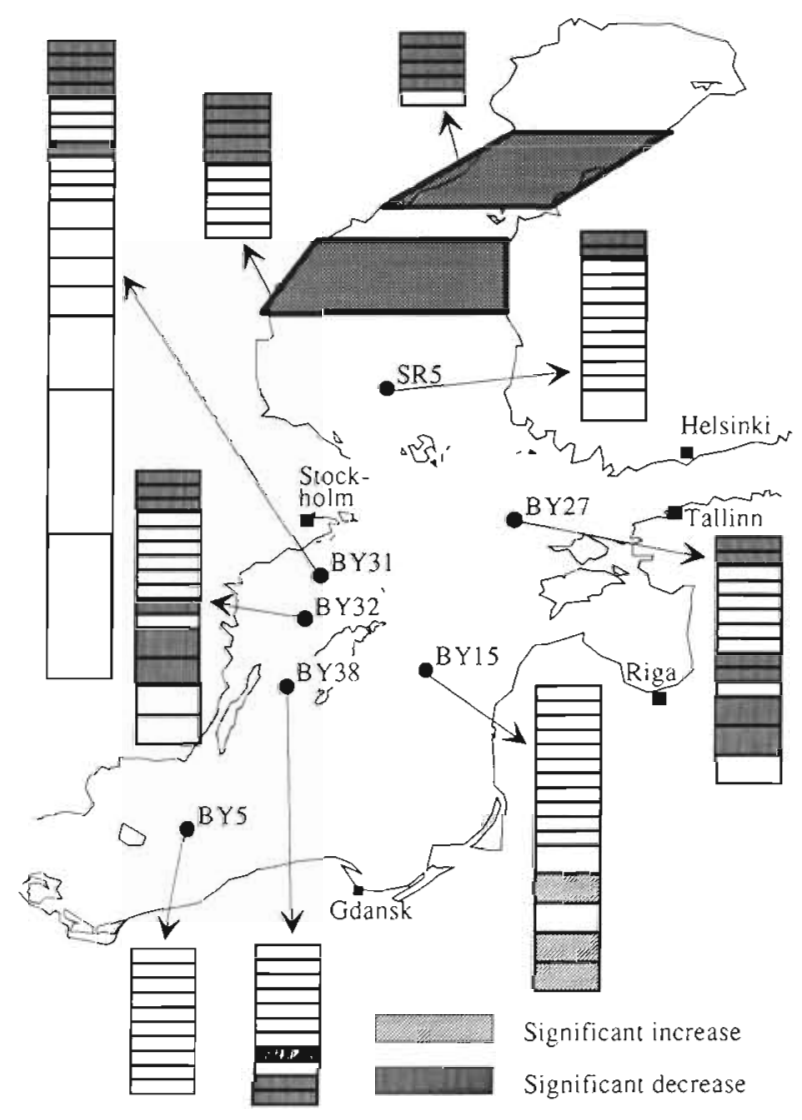

Fig. 7. Baltic Sea showing the location of hydrographic stations used in the nonparametric trend analysis of DSi concentrations and an overview of the results from the trend test (from Sanden et al. 1991). The 2 regions in the Gulf of Bothnia are indicated by shadowed bands. Only those trends that were significant $(p<0.5)$ without the assumption of independent observations are shown. Bars denote depth intervals $(10 \mathrm{~m}$ depth intervals in the upper $110 \mathrm{~m}$ of the water column) at hydrographic stations that were tested for trends.

Reprinted with permission of John Wiley \& Sons, Ltd 
now been noted in all basins of the Baltic (Wulff et al 1993). In addition to changes in water column DSi concentrations, there are now reports of an accompanying increase in siliceous microfossil accumulation with a change in species composition of diatoms preserved in Baltic Sea sediments (Miller \& Risberg 1990, Risberg 1990). These changes are reminiscent of the reports for the North American Great Lakes.

The rate of DSi depletion observed for the Baltic $\left\{0.2\right.$ to $0.8 \mu \mathrm{M} \mathrm{yr}^{-1}$; Sanden et al. 1991$\}$ is considerably less than the rate observed for freshwater systems [3.3 $\mu \mathrm{M} \mathrm{yr}^{-1}$ for Lake Michigan (Schelske 1988), $6.0 \mu \mathrm{M} \mathrm{yr}^{-1}$ for the Mississippi River (Turner \& Rabalais 1991)]. Regional trends in the Baltic Sea suggest that the long-term changes in the DSi depletion rate are significantly related to salinity (Fig. 8). There are many factors which may influence dissolution of diatom silica and thus ultimately the rate of DSi depletion, such as depth, $\mathrm{pH}$, temperature, nutrient loading, etc., however, salinity does also play an important role in the regeneration of biogenic silica. The rate of dissolution of biogenic silica increases by a factor of 2 by changing the salinity from 1 to $5 \%$ (Hurd 1983).

\section{Kattegat}

There is a clear long-term (1971 to 1982) increase in both total $\mathrm{N}$ and total $\mathrm{P}$ concentrations in the waters of the Kattegat (Andersson \& Rydberg 1988) and declines in DSi concentrations (1974 to 1988) have also been

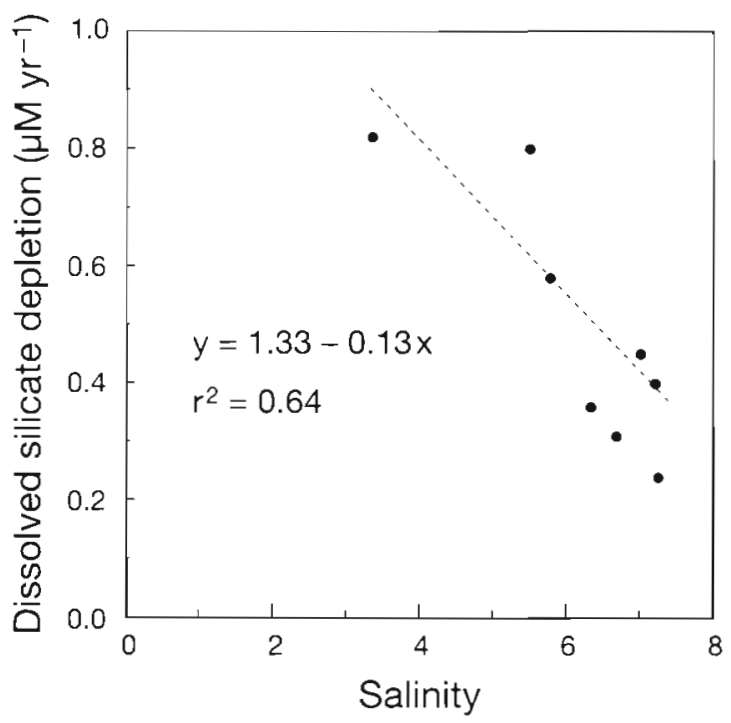

Fig. 8. Long-term mean surface layer (0 to $30 \mathrm{~m}$ ) DSi depletion in the Baltic Sea calculated for the time period 1968 to 1986 by non-parametric trend analysis as reported in Sandén et al. (1991) as a function of mean surface layer ( 0 to $30 \mathrm{~m}$ ) salinity for hydrographic stations shown in Fig. 7 reported (Møhlenberg 1991). Because the largest water inputs to the Kattegat are from the Baltic Sea, it is not known to what extent the outflowing water from the Baltic Sea has influenced these trends in comparison to the amount of DSi depletion occurring locally.

\section{Chesapeake Bay}

In the heavily enriched Chesapeake Bay estuary, Conley \& Malone (1992) have shown that the magnitude of the spring diatom bloom is controlled by DSi availability and that DSi limitation causes the collapse of the spring bloom, leading to floristic changes in phytoplankton communities. Accumulations of diatom biomass during the spring bloom, which are driven largely by inputs of DSi during the spring freshet, provide the organic matter that fuels the anoxia observed during summer months in Chesapeake Bay (Malone 1992).

\section{Gulf of Mexico}

Dortch \& Whitledge (1992) reported that DSi was likely to limit diatom production on the continental shelf of the Gulf of Mexico influenced by the Mississippi River plume. A recent analysis has shown that the frequency of potential nutrient limitation by DSi has increased substantially (Justić et al. unpubl.). Dortch \& Whitledge (1992) and Dortch et al. (1992) examined the role of DSi in determining species composition, trophodynamics and the fate of carbon and hypoxia on the Louisiana continental shelf. These topics will be covered in detail later in this review.

\section{North Sea}

Exhaustion of DSi while $N$ and $P$ are still present has been hypothesized to be responsible for extensive blooms of Phaeocystis sp. in North Sea coastal waters (Fransz \& Verhagen 1985, Veldhuis et al. 1986). A recent review of North Sea phytoplankton does not support this hypothesis (Reid et al. 1990), although it is clear that DSi is the nutrient limiting diatom growth during spring (Brockmann et al. 1990), especially in eutrophic coastal waters (Gieskes \& van Bennekom 1975, van Bennekom et al. 1975). DSi concentrations in the German Bight have decreased dramatically from 1966 to 1984 with seasonal low concentrations observed for longer time periods (Radach et al. 1990). Egge \& Aksnes (1992) have reported experimental evidence that suggests DSi may be important in determining changes in species composition of phyto- 
plankton assemblages. Egge \& Aksnes (1992) observed in mesocosm experiments that dominance of Phaeocystis sp. appeared only after the bloom of another species, but never at high concentrations of DSi (Fig. 1). Diatom standing crops can be increased by the addition of DSi to experimental mesocosms (Doering et al. 1989, Egge \& Aksnes 1992).

\section{ECOLOGICAL IMPLICATIONS}

Several recent articles have examined the role of DSi in ecosystem processes, especially changes in diatom species composition and food web dynamics (Officer \& Ryther 1980, Ryther \& Officer 1981, Doering et al. 1989, Smayda 1989, 1990, Dortch et al. 1992, Egge \& Aksnes 1992). Our purpose here is to summarize some of the changes that occur, not only in terms of species composition, but also in terms of changes in nutrient dynamics.

\section{Changes in species composition}

Many factors acting independently and/or cumulatively undoubtedly influence phytoplankton species composition and succession in nature. It has been clearly shown that the ratios of nutrients present (Tilman et al. 1982) and availability of DSi (Egge \& Aksnes 1992) can regulate phytoplankton assemblage species composition and biomass. Growth of diatoms depends on the presence of DSi, whereas growth of non-diatom phytoplankton does not. When DSi concentrations become low, other types of algae that do not require DSi can dominate phytoplankton assemblages and decrease the relative importance of diatoms in phytoplankton communities (Fig. 1). The frequency of changes in species composition and dominance by non-diatom phytoplankton communities will undoubtedly increase as DSi concentrations are depleted with eutrophication.

\section{Role in novel and toxic phytoplankton blooms}

Smayda (1989, 1990) proposed that increases in novel and toxic phytoplankton blooms observed globally and locally (Burkholder et al. 1992) are a direct consequence of increases in total $\mathrm{N}$ and total $\mathrm{P}$ concentrations and consequent modification of the Si: $\mathrm{N}$ and Si:P molar ratios. These nutrient changes progressively reduce the competitive advantage of diatoms, favoring replacement by other phylogenetic groups. Such a scenario has been described for formation of the exceptional 1988 Chrysochromulina polylepis bloom in Scandinavian coastal waters (Maestrini \& Granéli 1991). Integrating various sources of information, Maestrini \& Granéli (1991) describe a sequence of events suggesting that, prior to formation of the C. polylepis bloom, the winterspring diatom bloom exhausted the euphotic layer of DSi, leaving a phosphorus-poor but nitrogen-rich environment that allowed the rapid growth of an unusual bloom of a sometimes toxic algal species, $C$. polylepis. It is possible that long-term increases in $\mathrm{N}$ and $\mathrm{P}$ concentration (Andersson \& Rydberg 1988), coincident with long-term decreases in DSi concentration observed for Scandinavian coastal waters (Wulff \& Rahm 1988, Møhlenberg 1991), may now allow such an unusual sequence of events to occur more frequently.

The role of DSi may also be important in the formation of toxic algal blooms through the production of domoic acid, a neurotoxin correlated with shellfish poisoning (Bates et al. 1991) and brown pelican mortality (Buck et al. 1992), by the diatom Nitzschia pungens f. multiseries and a related diatom Pseudonitzschia australis. Bates et al. (1991) were only able to induce domoic acid production in $N$. pungens $\mathrm{f}$. multiseries during the stationary phase of the cell cycle when cell division was stopped by DSi limitation and nitrate was still available to produce the nitrogen-containing compound domoic acid.

\section{Changes in food webs}

Diatoms are the preferred food of many grazers and organisms in the upper trophic levels and thus form the basis for many of our productive fisheries (Ryther 1969). For example, upwelling regions, where diatoms are the predominant primary producers, are some of the biologically most productive regions of the world's oceans and support some of its largest and most important fisheries (Ryther 1969). Diatoms have been suggested to enhance the transfer of energy to higher trophic levels (Doering et al. 1989), either through fewer trophic links (Ryther 1969) or higher food quality. Since diatom abundance is partly determined by the availability of DSi, reductions in DSi availability, and ultimately the presence or absence of diatoms, may have a significant impact on the structure and functioning of the entire food web (Townsend \& Cammen 1988). Perturbations in the biogeochemical cycle of silica observed in many freshwater and coastal marine systems, therefore, may have far-reaching repercussions on the food webs and trophic structure of aquatic systems.

\section{Nutrient trapping}

Modification in the species composition of phytoplankton. cummunities has the potential to change the 
efficiency of nutrient recycling. It is well known that diatoms readily sink out of the upper layers (Smetacek 1985) and may comprise the bulk of nutrient flux, even when diatoms are not the dominant phytoplankton in the water column (Dortch et al. 1992). It is generally accepted that, when DSi concentrations become low or limiting to diatoms, sinking rates can increase dramatically (Titman \& Kilham 1976, Bienfang et al. 1982) leading to a sudden termination of a diatom bloom and a massive, rapid settling of fresh organic matter to the sediments (Smetacek 1985 and references therein). As diatoms sink, they bring with them other sequestered nutrients in their cytoplasm such as $\mathrm{N}$ and $\mathrm{P}$. Therefore any phytoplankton production that occurs in surface waters during summer months is often limited by recycling processes within the upper water column and by the transfer of new nutrient inputs from below by the physical processes of mixing. However, if we reduce the magnitude of the spring diatom bloom through longterm DSi depletion we will ultimately reduce the settling flux of diatoms, thus decreasing the amount of nutrients lost from surface layers. An excess of nutrients remaining in the euphotic zone after the spring diatom bloom may lead to larger summer phytoplankton blooms, decreasing water transparencies, greater eutrophication, and perhaps an increased frequency of novel phytoplankton blooms as described above.

\section{Role in oxygen dynamics}

The potential for a reduced settling flux of diatoms with declines in DSi concentrations also has repercussions on dissolved oxygen cycling and depletion. Clearly, if the reservoir of DSi is reduced, one would expect a concurrent reduction in the proportion of diatoms in the phytoplankton community, as well as a reduced flux of material settling to the bottom. In Chesapeake Bay (Malone 1992) and the Louisiana continental shelf (Dortch et al. 1992), the vertical flux of diatoms influences the severity and extent of hypoxia. It has been hypothesized (Turner \& Rabalais 1991, Dortch et al. 1992) that a reduction in the flux of easily degradable organic material to the sediment-water interface, e.g. enhanced limitation of diatom production by DSi supplies, may lead to improvements in oxygen conditions in bottom waters of the Louisiana continental shelf.

\section{Management implications}

As detailed above there are serious ecosystem repercussions resulting from modification of silica biogeochemical cycles with eutrophication in aquatic systems. Reductions in water column DSi concentra- tions may allow for changes in species composition and food web dynamics, an increased frequency of novel and toxic phytoplankton blooms, and altered nutrientrecycling pathways. Man cannot alter the inputs of DSi to aquatic ecosystems to any significant extent; they are essentially uncontrollable and result from weathering reactions in the watershed. These considerations highlight the importance of management strategies which have the goal of reducing the input of $\mathrm{P}$ and $\mathrm{N}$ to aquatic ecosystems. In order to diminish the threat of potentially devastating ecosystem alterations and conserve ecosystem health, we must continue to reduce nutrient inputs. In many cases, implementing only end-of-the-pipe technologies to reduce point loads will not be adequate without implementation of alternative ecotechnological measures to reduce non-point source inputs. In many ecosystems of the world, such as the Baltic Sea, the goal of reducing eutrophication effects may not be realized for the next 50 yr (Wulff \& Niemi 1992). It is clear that management strategies incorporating both ecological and economic processes toward a sustainable society are urgently needed.

\section{LITERATURE CITED}

Admiraal, W.. Breugem, P., Jacobs, D. M. L. H. A, de Ruyter Van Steveninck, E. D. (1990). Fixation of dissolved silicate and sedimentation of biogenic silicate in the lower Rhine during diatom blooms. Biogeochemistry 9: 175-185

Andersson, L., Rydberg, L. (1988). Trends in nutrient and oxygen conditions within the Kattegat: effects of local nutrient supply. Estuar. coast. Shelf Sci. 26: 559-579

Bates, S. S., de Freitas, A. S. W., Milley, J. E., Pocklington, R., Quilliam, M. A., Smith, J. C., Worms, J. (1991). Controls on domoic acid production by the diatom Nitzschia pungens f. multiseries in culture: nutrients and irradiance. Can. J. Fish. Aquat. Sci. 48: 1136-1144

Bienfang, P. K., Harrison, P. J., Quarmby, L. M. (1982) Sinking rates response to depletion of nitrate, phosphate and silicate in four marine diatoms. Mar. Biol. 67: 295-302

Brockmann, U. H., Laane, R. W. P. M., Postma, H. (1990). Cycling of nutrient elements in the North Sea. Neth. J. Sea Res. 26: 239-264

Brush, G. S., Davis, F. W. (1984). Stratigraphic evidence of human disturbance in an estuary. Quat. Res. 22: 91-108

Buck, K. R., Uttal-Cooke, L., Pilskaln, C. H., Roelke, D. L. Villac, M. C., Fryxell, G. A., Cifuentes, I., Chavez, F. P. (1992). Autecology of the diatom Pseudonitzschia australis, a domoic acid producer, from Monterey Bay, California. Mar. Ecol. Prog. Ser. 84: 293-302

Bukaveckas, P. A., Likens, G. E. (1992). Long-term changes in nutrient inputs to Mirror Lake. Am. Soc. Limnol. Oceanogr. Aquat. Sci. Meeting, Santa Fe, NM (abstract)

Burkholder, J. M., Noga, E. J., Hobbs, C. H., Glasgow, H. B. Jr, Smith, S. A. (1992). New 'phantom' dinoflagellate is the causative agent of major estuarine fish kills. Nature 358: $407-410$

Chapra, S. C. (1977). Total phosphorus model for the Great Lakes. J environ. Eng. Div., Am. Soc. civ. Eng. 103: $147-161$

Conley, D. J., Malone, T. C. (1992). Annual cycle of dissolved 
silicate in Chesapeake Bay: implications for the production and fate of phytoplankton biomass. Mar. Ecol. Prog. Ser. 81. 121-128

Conley, D. J , Schelske, C. L. (1989). Processes controlling the benthic regeneration and sedimentary accumulation of biogenic silica in Lake Michigan. Arch. Hydrobiol. 116: $23-43$

Conway, H. L., Parker, J. I., Yaguchi, E. M., Mellinger, D. L. (1977). Biological utilization of silicon in Lake Michigan. J. Fish. Res. Bd Can. 34: 537-544

Degobbis, D. (1989). Increased eutrophication of the northern Adriatic Sea. Second Act. Mar. Pollut. Bull. 20: 452-457

Doering, P. H., Oviatt, C. A., Beatty, L. L., Banzon, V. F., Rice, R., Kelly, S. P., Sullivan, B. K., Frithsen, J. B. (1989). Structure and function in a model coastal ecosystem: silicon, the benthos and eutrophication. Mar. Ecol. Prog. Ser. 52: 287-299

Dortch, Q., Milsted, D., Rabalais, N. N., Lohrenz, S. E., Redalje, D. G., Dagg, M. J., Turner, R. E., Whitledge, T. E. (1992). Role of silicate availability in phytoplankton species composition and the fate of carbon. Proc. NOAA. Nutrient Enhanced Coastal Ocean Productivity Program Synthesis Meeting, LUMCON, Oct. 1991. Texas Sea Grant Technical Publication TAMU-SG-92-108, College Station, p. $76-83$

Dortch, Q., Whitledge, T E. (1992). Does nitrogen or silicon limit phytoplankton production in the Mississippi River plume and nearby regions? Cont. Shelf Res. 12: 1293-1309

Edgington, D. N. (1984). Great Lakes eutrophication: fish, not phosphates? In: The future of Great Lakes resources. 1982-84 Biennial Report, Univ. Wisconsin Sea Grant Inst., Madison, p. 25-31

Edmondson, T (1991). The uses of ecology. Lake Washington and beyond. University of Washington Press, Seattle

Egge, J. K., Aksnes, D. L. (1992). Silicate as regulating nutrient in phytoplankton competition. Mar. Ecol. Prog. Ser. 83: $281-289$

Engstom, D. R., Swain, E. B., Kingston, J. C. (1985). A palaeolimnological record of human disturbance from Harvey's Lake, Vermont: geochemistry, pigments, and diatoms. Freshwat. Biol. 15: 261-288

Fransz, H. G., Verhagen, J. H. G. (1985). Modelling research on the production cycle of phytoplankton in the southern bight of the North Sea in relation to riverborne nutrient loads. Neth. J. Sea Res. 19: $241-250$

Frederick, V. R. (1981). Preliminary investigations of the algal flora in the sediments of Lake Erie. J. Great Lakes Res. 7: $404-408$

Garber, J. H. (1984). Laboratory study of nitrogen and phosphorus remineralization during decomposition of coastal plankton and seston. Estuar. coast. Shelf Sci. 18: 685-702

Gieskes, W. W. C, van Bennekom, A. J. (1975). Unreliability of the ${ }^{14} \mathrm{C}$ method for estimating primary productivity in eutrophic Dutch coastal waters. Limnol. Oceanogr. 18: $494-495$

Harris, G. P., Vollenweider, R. A. (1982). Paleolimnological evidence of early eutrophication in Lake Erie. Can. J. Fish. Aquat. Sci. 39: 618-626

Hecky, R. E., Kilham, P. (1988). Nutrient limitation of phytoplankton in freshwater and marine environments: a review of recent evidence on the effects of enrichment. Limnol. Oceanogr. 33: 796-822

Hurd, D. C. (1983). Physical and chemical properties of siliceous skeletons. In: Aston, S. R. (ed.) Silicon geochemistry and biogeochemistry. Academic Press, London, p. $187-244$

Hutchinson, G. E. (1967). A treatise on limnology, Vol. II,
An introduction to lake biology and the limnoplankton. J. Wiley, New York, p. 115

Justić, D., Legović, T. Rottini-Sandrini, L. (1987). Trends in oxygen content 1911-1984 and occurrence of benthic mortality in the northern Adriatic Sea. Estuar. coast. Shelf Sci. 25: 435-445

Kilham, P. (1971). A hypothesis concerning silica and the freshwater planktonic diatoms. Limnol. Oceanogr. 16: 10-18

Maestrini, S. Y., Granéli, E. (1991). Environmental conditions and ecophysiological mechanisms which led to the 1988 Chrysochromulina polylepis bloom: an hypothesis. Oceanol. Acta 14: 397-413

Malone, T C. (1992). Effects of water column processes on dissolved oxygen: nutrients, phytoplankton, and zooplankton. In: Smith, D., Leffler, M., Mackiernan, G. (eds.) Oxygen dynamics in Chesapeake Bay: a synthesis of results. Maryland Sea Grant College, College Park, p. $61-148$

Mayer, L. M., Gloss, S. P. (1980). Buffering of silica and phosphorus in a turbid river. Limnol. Oceanogr. 25: 12-22

Miller, U., Risberg, J (1990). Environmental changes, mainly eutrophication, as recorded by fossil siliceous microalgae in two cores from the uppermost sediments of the northwestern Baltic. Beih. Nova Hedwigia 100: 237-253

Møhlenberg, F. (1991). Plankton. Annual Report, Danish National Environmental Research Institute, Copenhagen, p. $63-65$

Officer, C. B., Ryther, J. H. (1980). The possible importance of silicon in marine eutrophication. Mar. Ecol. Prog. Ser. 3: $83-91$

Parker, J. I., Edgington, D. N. (1976). Concentration of frustules in Lake Michigan sediment cores. Limnol. Oceanogr. 21: $887-893$

Pokras, E. M. (1986). Preservation of fossil diatoms in Atlantic sediment cores: control by supply rate. Deep Sea Res. 33: $893-902$

Powers, C. F., Ayers, J. C. (1967). Water quality and eutrophication trends in southern Lake Michigan. In: Ayers, J. C.. Chandler, D. C. (eds.) Studies on the environment and eutrophication of Lake Michigan. Great Lakes Res. Div. Spec. Rep. No. 30. University of Michigan, Ann Arbor, p. $142-178$

Puškarić, S., Berger, G. W., Jorissen, F. J. (1990). Successive appearance of subfossil phytoplankton species in Holocene sediments of the northern Adriatic and its relation to the increased eutrophication pressure. Estuar, coast. Shelf Sci. 31: 177-187

Radach, G., Berg, J., Hagmeier, E. (1990). Long-term changes of the annual cycles of meteorological, hydrolographic, nutrient and phytoplankton time series at Helgoland and at LV ELBE 1 in the German Bight. Cont. Shelf Res. 10 $305-328$

Reid, P. C., Lancelot, C., Gieskes, W. W. C., Hagmeier, E., Weichart, G. (1990). Phytoplankton of the North Sea and its dynamics: a review. Neth. J. Sea Res. 26: 295-331

Risberg, J. (1990). Siliceous microfossil stratigraphy in a superficial sediment core from the northwestern part of the Baltic proper. Ambio 19: 167-172

Ryther, J. H. (1969). Photosynthesis and fish production in the sea. The production of organic matter and its conversion to higher forms of life vary throughout the world ocean. Science 166: 72-76

Ryther, J. H., Dunstan, W. M. (1971). Nitrogen, phosphorus and eutrophication in the coastal marine environment. Science 171. 1008-1013

Ryther, J. H., Officer, C. B. (1981). Impact of nutrient enrichment on water uses. In: Neilson, B. J., Cronin, L. E. 
(eds.) Estuaries and nutrients. Humana Press, Clifton, NJ, p. $247-261$

Sandén, P., Rahm, L., Wulff, F. (1991). Non-parametric trend test of Baltic Sea data. Environmetrics 2: 263-278

Scavia, D., Fahnenstiel, G. L. (1987). Dynamics of Lake Michigan phytoplankton: mechanisms controlling epilimnetic communities. J. Great Lakes Res. 13: 103-120

Schelske, C. L. (1985a). Biogeochemical silica mass balances in Lake Michigan and Lake Superior. Biogeochemistry 1. $197-218$

Schelske, C. L. (1985b). Silica depletion in Lake Michigan; verification using Lake Superior as an environmental reference standard. J. Great Lakes Res. 11: 492-500

Schelske, C. L. (1988). Historic trends in Lake Michigan silica concentrations. Int. Revue ges. Hydrobiol. 73: 559-591

Schelske, C. L. (1991). Historical nutrient enrichment of Lake Ontario: paleolimnological evidence. Can. J. Fish. Aquat. Sci. 48: $1529-1538$

Schelske, C. L., Conley, D. J., Stoermer, E. F., Newberry, T. L., Campbell, C. D. (1986a). Biogenic silica and phosphorus accumulation in sediments as indices of eutrophication in the Laurentian Great Lakes. Hydrobiologia 143: 79-86

Schelske, C. L., Conley, D. J., Warwick, W.F. (1985). Historical relationships between phosphorus loading and biogenic silica accumulation in Bay of Quinte sediments. Can. J. Fish. Aquat. Sci. 42: 1401-1409

Schelske, C. L., Hodell, D. A. (1991). Recent changes in productivity and climate of Lake Ontario detected by isotopic analysis of sediments. Limnol. Oceanogr. 36: 961-975

Schelske, C. L., Robbins, J. A., Gardner, W. D., Conley, D. J., Bourbonniere, R. A. (1988). Sediment record of biogeochemical responses to anthropogenic perturbations of nutrient cycles in Lake Ontario. Can. J Fish. Aquat. Sci. 45: $1291-1303$

Schelske, C. L., Stoermer, E. F. (1971). Eutrophication, silica depletion, and predicted changes in algal quality in Lake Michigan. Science 173: 423-424

Schelske, C. L., Stoermer, E. F. (1972). Phosphorus, silica and eutrophication in Lake Michigan. In: Likens, G. E. (ed.) Nutrients and eutrophication. Am. Soc. Limnol. Oceanogr., Lawrence, KS, p. 157-171

Schelske, C. L., Stoermer, E. F., Conley, D. J., Robbins, J. A., Glover, R. (1983). Early eutrophication in the lower Great Lakes: new evidence from biogenic silica in sediments. Science 222: $320-322$

Schelske, C. L., Stoermer, E. F., Fahnenstiel, G. L., Haibach, M. (1986b). Phosphorus enrichment, silica utilization, and biogeochemical silica depletion in the Great Lakes. Can. J. Fish. Aquat. Sci. 43: 407-415

Schelske, C. L., Züllig, H., Boucherle, M. (1987). Limnological investigation of biogenic silica sedimentation and silica biogeochemistry in Lake St. Moritz and Zürch. Schweiz. Z. Hydrol. 49: 42-50

Schindler, D. (1977). Evolution of phosphorus limitation in lakes. Science 195: 260-262

Shapiro, J., Swain, E. B. (1983). Lessons for the silica 'decline' in Lake Michigan. Science 221: 457-459

Smayda, T J. (1989). Primary production and the global epidemic of phytoplankton blooms in the sea: a linkage? In: Cosper, E. M., Bricelj, V. M., Carpenter, E. J. (eds.) Coastal and estuarine studies, Vol. 35, Novel phytoplankton blooms. Springer-Verlag, New York, p. 449-483

Smayda, T J. (1990). Novel and nuisance phytoplankton blooms in the sea: evidence for a global epidemic. In: Granéli, E., Sundström, B., Edler, L., Anderson, D. M. (eds.) Toxic marine phytoplankton. Elsevier, Inc., Amsterdam, p. $29-40$
Smetacek, V. (1985). Role of sinking in diatom life-history cycles: ecological, evolutionary and geological significance. Mar. Biol. 84: 239-251

Stoermer, E. F. (1978). Phytoplankton as indicators of water quality in the Laurentian Great Lakes. Trans. Am. microsc. Soc. 97: 2-16

Stoermer, E. F. (1993). Evaluating diatom succession: some peculiarities of the Great Lakes case. J. Paleolimnol. 8: 71-83

Stoermer, E. F., Emmert, G., Schelske, C. L. (1989). Morphological variation of Stephanodiscus niagarae (Bacillariophyta) in a Lake Ontario sediment core. J. Paleolimnol. 2. $227-236$

Stoermer, E. F., Kociolek, J. P., Schelske, C. L., Conley, D. J. (1985a). Siliceous microfossil succession in the recent history of Lake Superior. Proc. Acad. nat. Sci. Philad. 137. 106-118

Stoermer, E. F., Kociolek, J. P., Schelske, C. L., Conley, D. J. (1987). Quantitative analysis of siliceous microfossils in the sediments of Lake Erie's central basin. Diatom Res. 2: $113-134$

Stoermer, E. F., Schelske, C. L., Wolin, J. A. (1990a). Siliceous microfossil succession in the sediments of McLeod Bay, Great Slave Lake, Northwest Territories. Can. J. Fish. Aquat. Sci. 47: 1865-1874

Stoermer, E. F., Schelske, C. L., Wolin, J. A., Conley, D. J. (1990b). Siliceous microfossil succession in Lake Michigan. Limnol. Oceanogr. 35: 959-967

Stoermer, E. F., Wolin, J A., Schelske, C. L., Conley, D. J. (1985b). An assessment of ecological changes during the recent hustory of Lake Ontario based on siliceous microfossils preserved in the sediments. J. Phycol. 21: 257-276

Stoermer, E. F., Wolin, J. A., Schelske, C. L., Conley, D. J. (1985c). Variation in Melosira islandica valve morphology related to eutrophication and silica depletion. Limnol. Oceanogr. 30: 414-418

Stoermer, E. F., Wolin, J. A., Schelske, C. L., Conley, D. J. (1985d). Post-settlement diatom succession in the Bay of Quinte, Lake Ontario. Can. J. Fish. Aquat. Sci. 42: $754-767$

Talling, J. F., Heaney, S. I. (1988). Long-term changes in some English (Cumbrian) lakes subjected to increased nutrient inputs. In: Round, F. E. (ed.) Algae and the aquatic environment. Titus Wilson \& Son Ltd, Kendal, p. 1-29

Theriot, E. C., Stoermer, E. F. (1984). Principal components analysis of character variation in Stephanodiscus niagarae Ehrenb.: morphological variation related to lake trophic status. Proc. 11 th int. Diatom Symp., Philadelphia. Otto Koeltz, Koeningstein, p. 97-111

Tilman, D., Kilham, S. S., Kilham, P. (1982). Phytoplankton community ecology: the role of limiting nutrients. A. Rev. Ecol. Syst. 13: 349-372

Titman, D., Kilham, P. (1976). Sinking in freshwater phytoplankton: some ecological implications of cell nutrient status and physical mixing process. Limnol. Oceanogr. 21: $409-417$

Townsend, D. W., Cammen, L. M. (1988). Potential importance of the timing of spring plankton blooms to benthicpelagic coupling and recruitment of juvenile demersal fishes. Biol. Oceanogr. 5: 215-229

Turner, R. E., Rabalais, N. N. (1991). Changes in Mississippi River water quality this century. BioSci. 41: 140-147

van Bennekom, A. J., Gieskes, W. W. C., Tijssen, S. B. (1975). Eutrophication of Dutch coastal waters. Proc. R. Soc. B 189: $359-374$

van Bennekom, A. J., Salomons, W. (1981). Pathways of nutrients and organic matter from land to ocean through 
rivers. In: Martin, J.-M., Burton, J D., Eisma, D. (eds.) River inputs to ocean systems. UNEP/UNESCO, Rome, p. $33-51$

VeIdhuis, M. J. W., Colijn, F., Venekamp, L. A. H. (1986). The spring bloom of Phaeocyctis pouchetii (Haptophycaea) in Dutch coastal waters. Neth. J. Sea Res. 20: $37-48$

Wahby, S. D., Bishara, N. F. (1980). The effect of the River Nile on Mediterranean water, before and after the construction of the High Dam at Aswan. In: Martin, J.-M., Burton, J. D., Eisma, D. (eds.) Proceedings of a SCOR workshop on river inputs to ocean systems, 26-30 March 1979, Rome, Italy. UNESCO, Paris, p. 311-318

Welch, H. E., Legault, J. A., Kling, H. J. (1989). Phytoplankton nutrients, and primary production in fertilized and natural

This review was submitted to the editor lakes at Saqvaquac, N.W.T Can. J. Fish. Aquat. Sci. 46 $90-107$

Wolin, J. A., Stoermer, E. F., Schelske, C. L., Conley, D. J. (1988). Siliceous microfossil succession in recent Lake Huron sediments. Arch. Hydrobiol 114: 175-198

Wulff, F., Niemi, A. (1992). Priorities for the restoration of the Baltic Sea - a scientific perspective. Ambio 21: 193-195

Wulff, F., Rahm, L. (1988). Long-term, seasonal and spatial variations of nitrogen, phosphorus and silicate in the Baltic: an overview. Mar. environ. Res. 26: 19-37

Wulff, F., Rahm, L., Rodriguez-Medina, M. (1993). Long-term and regional variations of nutrients in the Baltic Sea; 1972-1991. Finn. mar. Res. (in press)

Manuscript first received: January 23, 1993

Revised version accepted: June 23, 1993 